\title{
Pre-procedural fasting in emergency sedation
}

\author{
Rebecca J Thorpe, Jonathan Benger
}

\section{See Commentary, p 253}

University Hospitals Bristol Foundation Trust, Bristol, UK

\section{Correspondence to}

Dr Rebecca J Thorpe; r.j.preece@doctors.org.uk

Accepted 21 June 2009

\section{ABSTRACT}

Emergency physicians frequently undertake emergency procedural sedation in non-fasted patients. At present, no UK guidelines exist for pre-procedural fasting in emergency sedation, and guidelines from the North American Association of Anesthesiologists (ASA) designed for general anaesthesia (GA) are extrapolated to emergency care. A systematic review of the literature was conducted with the aim of evaluating the evidence for risk of pulmonary aspiration during emergency procedural sedation in adults. All abstracts were read and relevant articles identified. Further literature was identified by hand-searching reference sections. Papers were objectively evaluated for relevance against predetermined criteria. The risk of aspiration in emergency procedural sedation is low, and no evidence exists to support pre-procedural fasting. In several large case series of adult and paediatric emergency procedural sedation, non-fasted patients have not been shown to be at increased risk of pulmonary aspiration. There is only one reported case of pulmonary aspiration during emergency procedural sedation, among 4657 adult cases and 17672 paediatric cases reviewed. Furthermore, ASA guidelines for fasting prior to GA are based on questionable evidence, and there is high-level evidence that demonstrates no link between pulmonary aspiration and non-fasted patients. There is no reason to recommend routine fasting prior to procedural sedation in the majority of patients at the Emergency Department. However, selected patients believed to be significantly more prone to aspiration may benefit from risk:benefit assessment prior to sedation.

\section{INTRODUCTION \\ Synopsis}

Emergency physicians frequently undertake emergency procedural sedation in non-fasted patients. At present, no UK guidelines exist for pre-procedural fasting in emergency sedation, and guidelines from the American Association of Anesthesiologists (ASA) designed for general anaesthesia (GA) are extrapolated. The literature shows that the risk of aspiration in emergency procedural sedation is low, and no evidence exists to support pre-procedural fasting. Furthermore, ASA guidelines for fasting prior to GA are based on questionable evidence, and there is high-level evidence that demonstrates no link between pulmonary aspiration and non-fasted patients.

\section{Background to procedural sedation}

The administration of procedural sedation has become widespread practice in UK Emergency Departments (ED). It allows potentially painful and distressing procedures to be undertaken in a timely fashion with minimal distress to the patient. Emergency physicians now increasingly possess the necessary skills to safely manage procedural sedation and its possible complications. Potentially life-threatening complications include apnoea, hypoxia, hypotension and pulmonary aspiration. To date, there has been only one published case report of pulmonary aspiration occurring during ED procedural sedation. ${ }^{1}$ The aim of this study was to evaluate the evidence for risk of pulmonary aspiration during emergency sedation in adults.

\section{Pathophysiology of pulmonary aspiration}

Pulmonary aspiration can be defined as 'the inhalation of oropharyngeal or gastric contents into the larynx and lower respiratory tract'. ${ }^{2}$ The consequences of pulmonary aspiration exist on a continuum from asymptomatic to fatal aspiration pneumonitis. The syndrome of aspiration pneumonitis describes a collection of features including cough, dyspnoea, hypoxia and bronchospasm, ${ }^{3}$ from which the majority of patients recover completely, and mortality is extremely rare. ${ }^{4}$

\section{Changing theories in risk of aspiration}

Mendelson was the first to describe the pathophysiology of aspiration of gastric contents as a consequence of general anaesthesia in $1946 .{ }^{5}$ Mendelson described a series of 44016 obstetric patients undergoing general anaesthesia between 1932 and 1945. He reported 45 cases of aspiration, resulting in two deaths. He went on to instil a variety of solutions into rabbit lungs and observed the consequences, and concluded that the severity of pulmonary damage in humans and animals is worse in large-volume, low-pH aspirate. He advocated the introduction of preoperative fasting to prevent aspiration of gastric acid, and subsequent studies aimed to determine the characteristic of stomach contents that were likely to produce aspiration pneumonitis. An oft-quoted study by Roberts in $1974^{6}$ concluded that the risk of aspiration pneumonitis is increased if the patient has gastric volumes exceeding 25 millilitres, with a $\mathrm{pH}$ less than 2.5. These values were extrapolated from work done on monkeys. It has been historically taught that the degree of pulmonary injury from aspiration is directly related to volume and acidity of gastric contents, a theory that has since been disproved. ${ }^{7-9}$ Similarly, there is insufficient evidence to show that a decreased preoperative fasting time is associated with an increased risk of pulmonary aspiration. ${ }^{10-14}$

Over the years, many theories have been proposed, and much research has focused on identification of risk factors for aspiration during general anaesthesia. The first studies on animals showed that lungs exposed to stomach acid demonstrated histological changes of chemical 
pneumonitis. ${ }^{5}$ Consequently, the use of antacid therapies began, in order to reduce the likelihood of pneumonitis occurring should pulmonary aspiration of gastric contents occur. However, although antacid medications have been shown to lower gastric $\mathrm{pH}$, there is no evidence that therapeutic prophylaxis lowers aspiration risk or improves outcomes ${ }^{15}$ and it is not recommended by the ASA in healthy patients. ${ }^{7}$ In obstetric anaesthesia, ASA guidelines advise anaesthetists to consider prophylaxis before caesarean delivery.

Another relevant theory is that a minimum volume of fluid needs to be aspirated into the lungs before a pneumonitis occurs, and that the gastric volume at the time of anaesthesia impacts on the volume aspirated. ${ }^{8}$ This has been superseded by more recent evidence, demonstrating that clear liquids ingested up to $2 \mathrm{~h}$ prior to surgery do not increase gastric volume or decrease gastric $\mathrm{pH} .{ }^{16}$ Significantly, aspiration of clear fluids is associated with a low risk of pneumonitis, ${ }^{17}$ and it is now recognised that asymptomatic aspiration of gastric contents occurs physiologically during normal sleep. ${ }^{2} 18$ Research on intubated patients during general anaesthesia shows that silent aspiration frequently occurs despite airway protection. ${ }^{19}{ }^{20}$ Perhaps most importantly, it appears that the aspiration of particulate matter or food can result in pulmonary damage. ${ }^{4}$ It is, therefore, the risk of particulate matter aspiration that should be the priority in the development of a guideline for procedural sedation.

Other factors have been implicated in the past such as pregnancy, obesity and opioid use, but these do not seem to be independent risk factors. ${ }^{3}$ Confirmed risk factors for pulmonary aspiration include airway difficulties (eg, laryngospasm, technically difficult intubation), old age and conditions predisposing to gastro-oesophageal reflux (eg, hiatus hernia, bowel obstruction, raised intracranial pressure). ${ }^{15}$ Significantly, pulmonary aspiration has also been reported in patients with no risk factors, ${ }^{4}$ and may still occur when the precaution of rapid sequence of induction of anaesthesia and tracheal intubation is employed. ${ }^{15}$ One theory of particular interest to emergency physicians, is that acutely stressful experiences can cause a delay in gastric emptying. ${ }^{21}$ However, this theory remains controversial, and although distress is often quoted as a risk factor for pulmonary aspiration secondary to delayed gastric emptying, several studies have failed to show an association. ${ }^{22-24}$

Regarding general anaesthesia, a Cochrane review in $2003^{8}$ concluded that "there is no evidence to suggest a shortened fluid fast results in an increased risk of aspiration, regurgitation or related morbidity compared with the standard'. However, despite the myriad literature there are relatively few trials that specifically investigate the relationship between preoperative fasting and the risk of pulmonary aspiration. Several randomised controlled trials (RCTs) ${ }^{9-14}$ indicate that despite deviance from ASA fasting guidelines there is no increased risk of pulmonary aspiration. It is difficult to apply this evidence to sedation in the emergency department for a number of reasons:

1. During general anaesthesia protective airway reflexes are lost, and airway manipulations are common. This is very different to sedated patients who do not usually undergo airway manipulations, and are presumed to maintain their airway reflexes in most cases.

2. The anaesthetic literature relates to elective procedures. Patients being sedated in emergency departments are, by definition, unplanned.

3. The alternative oral intake regimens trialled by these studies included small volumes of clear fluids (maximum of 400 millilitres), which is very different to patients undergoing sedation in the ED, who have usually had unlimited fluid and solid intake prior to attendance.

However, it is clear from up to date evidence, that the ASA guidelines for fasting are not based on recent clinical trials, and that the evidence that historically led to the development of fasting guidelines, which remain in place today, has minimal scientific support.

\section{Pulmonary aspiration in emergency procedural sedation}

Preoperative fasting guidelines have been extrapolated to procedural sedation. The ASA guidelines require at least $2 \mathrm{~h}$ of fasting for clear liquids and $6 \mathrm{~h}$ for solids, ${ }^{7}$ and indicate that this should also apply to 'light pre-procedural sedation'. These guidelines are now in widespread use in the UK, and have been incorporated into ED sedation protocols.

For clarity, the following definitions for sedation level will be used throughout this review. ${ }^{7}$

Table 1 represents an attempt to categorise the continuum of sedation into discrete stages in terms of level of responsiveness, effect on airway reflexes, spontaneous respiration and cardiovascular function. The spectrum of sedation begins at minimal, in which a patient has a normal response to verbal stimulation and is able to adequately protect their own airway. At the opposite end of the sedation spectrum, general anaesthesia is reached, and the patient can be unresponsive and apnoeic, with an obstructed airway. Although the aim of sedation is not to reach this state, it is recognised that this may inadvertently occur due to inappropriate dosing, the effects of polypharmacy or individual pharmacokinetics.

However, there are several theoretical reasons why the risk of aspiration can be considered to be lower in procedural sedation than in general anaesthesia:

1. Depth of sedation: Airway reflexes are broadly assumed to be maintained during minimal and moderate sedation, and lost during general anaesthesia. It is not clear where the point of loss of reflexes lies, or even if such a point exists. It is likely that a variety of factors, specific to each individual patient, determine the depth of sedation at which they become unable to protect themselves from significant aspiration. ${ }^{4}$ However, procedural sedation does not aim to provide sedation to the point of general anaesthesia, so in theory protective airway reflexes should be maintained, at least to some degree. Specifically, when ketamine is used for sedation airway reflexes are more likely to be preserved because of its dissociative effect.

Table 1 Categories of sedation

\begin{tabular}{|c|c|c|c|c|}
\hline & Minimal sedation & Moderate sedation & Deep sedation & General anaesthesia \\
\hline Responsiveness & $\begin{array}{l}\text { Normal response to } \\
\text { verbal stimulation }\end{array}$ & $\begin{array}{l}\text { Purposeful* response to } \\
\text { verbal or tactile stimulation }\end{array}$ & $\begin{array}{l}\text { Purposeful* response } \\
\text { following repeated or } \\
\text { painful stimulus }\end{array}$ & $\begin{array}{l}\text { Unrousable, even with } \\
\text { painful stimulus }\end{array}$ \\
\hline Airway reflexes & Unaffected & No intervention required & Intervention may be required & Intervention often required \\
\hline Breathing & Unaffected & Adequate & May be inadequate & Frequently inadequate \\
\hline Cardiovascular & Unaffected & Usually maintained & Usually maintained & May be impaired \\
\hline
\end{tabular}

${ }^{*}$ Reflex withdrawal from painful stimulus is NOT considered a purposeful response. 
2. Airway manipulation: During procedural sedation, airway manipulation does not routinely take place, unless there has been a complication. It is reported that two-thirds of aspirations during general anaesthesia occur during intubation or extubation. ${ }^{4}$

3. Drugs: The drugs used routinely for procedural sedation are thought to be less emetic than the inhaled anaesthetic gases used for general anaesthesia. ${ }^{25} 26$

4. Comorbidity of patients: Patients with pre-existing comorbidities have an increased risk of aspiration during general anaesthesia. ${ }^{17}$ Patients requiring sedation for emergency procedures in the ED should be assessed in terms of the risk of aspiration. In those at high risk it is usual practice for the procedure to be performed by an alternative method, for example general anaesthesia with formal airway protection, or regional anaesthesia.

There are many other reasons why the ASA guidelines for fasting for elective anaesthesia should no longer be used as the gold standard for sedation in ED. ${ }^{27}$ The guidelines are designed for a group of patients undergoing elective procedures, which is a very different target group from those found in the ED. It is often impractical to suggest fasting this group of patients before their procedure due to the urgency of the treatment required, for example, the cardioversion of a life-threatening dysrhythmia. Rigidly applying these guidelines could risk clinical deterioration, delay definitive treatment and cause ongoing pain and distress. These individuals represent a significant patient cohort, and in a busy ED there are not the facilities to house patients until they have reached the allocated period of fasting. ${ }^{27}$ Evidence in adults is limited, but a case series of children undergoing procedural sedation in the ED shows that although $56 \%$ were not fasted according to ASA guidelines, there was no difference in airway complications or emesis when compared with the fasted children. ${ }^{28}$ Indeed, only one case report ${ }^{1}$ exists of pulmonary aspiration during procedural sedation in the $\mathrm{ED}$, and this patient had no adverse outcome.

\section{AIMS}

There is a compelling need for a guideline to allow emergency physicians to practically and safely carry out procedural sedation, rather than extrapolating ASA guidelines. The aim of this article is to evaluate the evidence for risk of pulmonary aspiration during ED procedural sedation in adults.

\section{METHODS}

The aim was to identify literature that would provide evidence regarding fasting in adults undergoing emergency sedation. However, it was expected that there would be little evidence available. If this was the case, the literature search would be expanded to identify relevant related topics such as paediatric emergency sedation.

In the preliminary literature search, an electronic search was carried out, using the terms: [exp EMERGENCY] or [exp EMERGENCY TREATMENT] or [emergency.mp] AND [exp CONSCIOUS SEDATION/OR exp DEEP SEDATION/] or [sedation.mp] AND [procedur\$.mp]. Limit to Humans and (Age Groups All Adult 19 plus years) and English Language. Searches were made of the following databases via Athens: MEDLINE (1950 to 2008187 titles), EMBASE (1974 to 2008, 413 titles). All abstracts were read and relevant articles identified. Further literature was identified by hand-searching reference sections. Papers were assessed for relevance by applying the following inclusion criteria: (1) Design: case series, trials, cohorts. (2) Population: studies recruiting adult patients undergoing sedation for emergency procedures. (3) Interventions: Sedation for urgent procedures carried out in ED. (4) Outcome measures: adverse effects reported. Exclusion criteria: studies that did not document fasting status, and whose authors, when contacted, could not provide information on fasting status in the study population.

Due to the lack of conclusive evidence in the published literature regarding fasting in adult procedural sedation, a search was also conducted for evidence in paediatric emergency medicine. An electronic search was carried out, using the same terms as above, but also limited to 'paediatric'. Searches were made of the following databases using the NHS library via Athens: MEDLINE (1950-2008, 226 titles), EMBASE (1974-2008, 423 titles). All abstracts were read and relevant articles identified. Further literature was identified by hand-searching reference sections. The same inclusion and exclusion criteria were applied. The results of the two literature searches will be discussed in two separate parts.

\section{ADULT PROCEDURAL SEDATION \\ Results}

One case report of pulmonary aspiration associated with sedation has been published to date, summarised in table $2 .{ }^{1}$

Several large series were identified in the literature search. None of these papers specifically addressed the risk of pulmonary aspiration in procedural sedation. However, all the papers listed in table 3 specifically reported any adverse events occurring procedural sedation, of which vomiting and pulmonary aspiration were specifically included.

\section{Comment}

With the exception of one case report, there are no reports of pulmonary aspiration associated with emergency procedural sedation in the literature. However, cases of vomiting during sedation are described. In total 4657 cases of emergency sedation appear in table 3, all of which describe adults requiring emergency procedures, using a variety of sedative drugs, who had not been fasted according to ASA guidelines. In total, 17 cases of vomiting were reported during sedation, but none of the patients who vomited showed evidence of pulmonary aspiration. Of the cases that vomited during procedural sedation, one was being intubated for decreased level of consciousness, and was later found to have had a hypertensive intracranial haemorrhage prior to sedation. Another patient vomited after a period of apnoea for which they received bag-valve-mask ventilation (but no airway manipulation). The other cases had no specific additional cause for vomiting reported.

Table 2 Case report

\begin{tabular}{|c|c|c|c|c|}
\hline Reference & Subjects & Study design & Findings & Comments \\
\hline Cheung $^{1} 2007$ & $\begin{array}{l}\text { Single patient, fasted for } \\
5 \mathrm{~h} \text { undergoing manipulation } \\
\text { of a fractured ankle }\end{array}$ & Case report & $\begin{array}{l}\text { Pulmonary aspiration } \\
\text { occurred }\end{array}$ & $\begin{array}{l}\text { Alcohol consumed. } \\
\text { Sedated on two occasions. } \\
\text { Sedation administered by } \\
\text { orthopaedic team }\end{array}$ \\
\hline
\end{tabular}


Table 3 Summary of adult sedation papers

\begin{tabular}{|c|c|c|c|c|}
\hline Reference & Subject & Study design & Findings & Comments \\
\hline Frazee $\mathrm{BW}^{71}$ & 136 patients sedated using propofol & Prospective observational study & $\begin{array}{l}\text { One patient vomited, after apnoea } \\
\text { requiring assisted ventilation: } \\
\text { no evidence of aspiration }\end{array}$ & $\begin{array}{l}\text { Patients fasted for } 6 \mathrm{~h} \\
\text { for solids, } 2 \mathrm{~h} \text { for liquids }\end{array}$ \\
\hline Campbell SG ${ }^{72}$ & $\begin{array}{l}979 \text { patients sedated using propofol, } \\
\text { fentanyl or midazolam }\end{array}$ & Retrospective case series & $\begin{array}{l}\text { No cases of vomiting or aspiration } \\
\text { reported }\end{array}$ & Patients not fasted \\
\hline Miner $\mathrm{JR}^{73}$ & $\begin{array}{l}62 \text { patients, ASA three or four sedated } \\
\text { using propofol or etomidate }\end{array}$ & Prospective observational study & $\begin{array}{l}\text { No cases of vomiting or aspiration } \\
\text { reported }\end{array}$ & Fasted for $3 \mathrm{~h}$ for solids \\
\hline Swanson $\mathrm{ER}^{74}$ & $\begin{array}{l}20 \text { patients sedated using propofol and } \\
\text { fentanyl }\end{array}$ & Convenience sample & $\begin{array}{l}\text { No cases of vomiting or aspiration } \\
\text { reported }\end{array}$ & Patients not fasted \\
\hline Chudnofsky $\mathrm{CR}^{75}$ & $\begin{array}{l}77 \text { patients sedated using ketamine and } \\
\text { midazolam }\end{array}$ & Prospective observational trial & $\begin{array}{l}\text { Two cases of post-procedural } \\
\text { vomiting, no aspiration }\end{array}$ & Patients not fasted \\
\hline Lermann $B^{76}$ & 76 patients sedated using methohexital & Prospective observational study & $\begin{array}{l}\text { One patient vomited, who was being } \\
\text { intubated for a low GCS. CT showed } \\
\text { hypertensive intracranial haemorrhage }\end{array}$ & Patients not fasted \\
\hline Miner $\mathrm{JR}^{77}$ & $\begin{array}{l}103 \text { patients sedated using propofol or } \\
\text { methohexital }\end{array}$ & Prospective randomised study & $\begin{array}{l}\text { No cases of vomiting or aspiration } \\
\text { reported }\end{array}$ & Fasted for $3 \mathrm{~h}$ for solids \\
\hline Vinson $\mathrm{DR}^{78}$ & $\begin{array}{l}134 \text { patients aged } 6-93 \text { sedated using } \\
\text { etomidate, opiates and benzodiazepines }\end{array}$ & Retrospective observational study & $\begin{array}{l}\text { One case of vomiting requiring } \\
\text { suctioning, no evidence of aspiration }\end{array}$ & Patients not fasted \\
\hline Ruth $\mathrm{WJ}^{79}$ & 60 patients sedated with etomidate & Two-part feasibility study & $\begin{array}{l}\text { One cases of post-procedural } \\
\text { vomiting. No cases of vomiting } \\
\text { while sedated, or aspiration }\end{array}$ & Patients not fasted \\
\hline Burton $\mathrm{JH}^{80}$ & 792 patients sedated with propofol & $\begin{array}{l}\text { Prospective observational study } \\
\text { at three sites }\end{array}$ & $\begin{array}{l}\text { One case of vomiting, no evidence } \\
\text { of aspiration }\end{array}$ & Patients not fasted \\
\hline Coll-Vinent $B^{81}$ & $\begin{array}{l}32 \text { patients sedated using propofol, } \\
\text { etomidate, midazolam } \pm \text { flumazenil }\end{array}$ & RCT of four regimes & $\begin{array}{l}\text { No cases of vomiting or aspiration } \\
\text { reported }\end{array}$ & Patients fasted for $4 \mathrm{~h}$ \\
\hline Miner $J^{82}$ & $\begin{array}{l}108 \text { patients sedated using propofol, } \\
\text { methohexitol, etomidate or } \\
\text { benzodiazepines }\end{array}$ & Prospective observational study & $\begin{array}{l}\text { No cases of vomiting or aspiration } \\
\text { reported }\end{array}$ & $\begin{array}{l}\text { Patients fasted for } \\
3 \mathrm{~h} \text { for solids }\end{array}$ \\
\hline Sokolowski $J^{83}$ & $\begin{array}{l}145 \text { patients over } 70 \text { years old sedated } \\
\text { using etomidate }\end{array}$ & Prospective observational study & $\begin{array}{l}\text { No cases of vomiting or aspiration } \\
\text { reported }\end{array}$ & Patients not fasted \\
\hline Willman $\mathrm{EV}^{84}$ & $\begin{array}{l}114 \text { patients sedated using ketamine and } \\
\text { propofol }\end{array}$ & Prospective observational study & $\begin{array}{l}\text { No cases of vomiting or aspiration } \\
\text { reported }\end{array}$ & Patients not fasted \\
\hline Chan $\mathrm{KLL}^{85}$ & $\begin{array}{l}87 \text { patient sedated using etomidate or } \\
\text { midazolam }\end{array}$ & $\mathrm{RCT}$ & $\begin{array}{l}\text { No cases of vomiting or aspiration } \\
\text { reported }\end{array}$ & Patients not fasted \\
\hline Sacchetti $A^{70}$ & 687 patients sedated using various agents & $\begin{array}{l}\text { Prospective multicentre } \\
\text { observational study }\end{array}$ & $\begin{array}{l}\text { No cases of vomiting or aspiration } \\
\text { reported }\end{array}$ & Patients not fasted \\
\hline Engel $J^{86}$ & 308 adults sedated using propofol & Prospective observational study & $\begin{array}{l}\text { No cases of vomiting or aspiration } \\
\text { reported }\end{array}$ & Patients not fasted \\
\hline Dunn $\mathrm{T}^{87}$ & 48 patients sedated using propofol & Prospective observational study & $\begin{array}{l}\text { No cases of vomiting or aspiration } \\
\text { reported }\end{array}$ & Patients not fasted \\
\hline Miner $J^{88}$ & $\begin{array}{l}214 \text { patients sedated using propofol or } \\
\text { etomidate }\end{array}$ & Randomised prospective trial & $\begin{array}{l}\text { No cases of vomiting or aspiration } \\
\text { reported }\end{array}$ & $\begin{array}{l}\text { Patients fasted for } \\
3 \mathrm{~h} \text { for solids }\end{array}$ \\
\hline Newton $A^{89}$ & 92 patients sedated using ketamine & Prospective observational study & $\begin{array}{l}\text { Three patients vomited, no reports } \\
\text { of aspiration }\end{array}$ & Patients not fasted \\
\hline Vardy $\mathrm{JM}^{90}$ & $\begin{array}{l}210 \text { patients sedated for emergency } \\
\text { procedures }\end{array}$ & Prospective observational study & $\begin{array}{l}\text { Three patients vomited, no reports } \\
\text { of aspiration }\end{array}$ & Patients not fasted \\
\hline $\operatorname{Sim} \mathrm{TB}^{91}$ & $\begin{array}{l}15 \text { patients sedated for abscess drainage } \\
\text { in the ED using ketamine and midazolam }\end{array}$ & Prospective observational study & $\begin{array}{l}\text { Two patients vomited, no reports } \\
\text { of aspiration }\end{array}$ & Patients fasted for $3 \mathrm{~h}$ \\
\hline Messenger $\mathrm{DW}^{92}$ & $\begin{array}{l}63 \text { patients sedated with ketamine or } \\
\text { fentanyl }\end{array}$ & Double blind RCT & $\begin{array}{l}\text { No cases of aspiration or vomiting } \\
\text { reported }\end{array}$ & $4 \mathrm{~h}$ fast recommended \\
\hline Wright SW ${ }^{93}$ & $\begin{array}{l}69 \text { patients sedated with midazolam and } \\
\text { diazepam }\end{array}$ & Double blind RCT & $\begin{array}{l}\text { No cases of aspiration or vomiting } \\
\text { reported }\end{array}$ & $\begin{array}{l}\text { Not routinely fasted. } \\
\text { Fasting times decided } \\
\text { on an individual basis }\end{array}$ \\
\hline Green $\mathrm{SM}^{94}$ & 26 patients sedated with ketamine & Prospective observational study & $\begin{array}{l}\text { Two patients vomited but no cases } \\
\text { of aspiration reported }\end{array}$ & Patients fasted for $3 \mathrm{~h}$ \\
\hline
\end{tabular}

ASA, American Society of Anesthesiologists; CT, computed tomography; GCS, Glasgow Coma Scale; RCT, randomised controlled trial.

In summary, there is no high-level evidence that specifically addresses the risk of pulmonary aspiration associated with sedation for emergency procedures. However, large numbers of patients are described in these studies, and there remains only one case report of pulmonary aspiration in the literature to date.

\section{PAEDIATRIC PROCEDURAL SEDATION}

Paediatric emergency physicians, like their counterparts in the adult $\mathrm{ED}$, are increasingly undertaking sedation for painful and unpleasant procedures such as suturing and joint/fracture manipulations. ${ }^{29}$ Similar to adult emergency sedation, there are no guidelines that specifically relate to sedation for paediatric emergency procedures. Again, the ASA guidelines are frequently applied to this group of patients, despite general acceptance that most procedural sedation is not likely to result in loss of protective airway reflexes. ${ }^{27}$ For emergency procedures, the ASA believes that the same fasting rules should apply as for elective procedures, that is, $2 \mathrm{~h}$ for clear liquids, $4 \mathrm{~h}$ after breast milk and $6 \mathrm{~h}$ after food or formula milk. ${ }^{7}$ The ASA states that if the patient is not starved and requires an emergency procedure, sedation should be modified to be lighter. ${ }^{7}$ 
Table 4 Summary of paediatric sedation papers

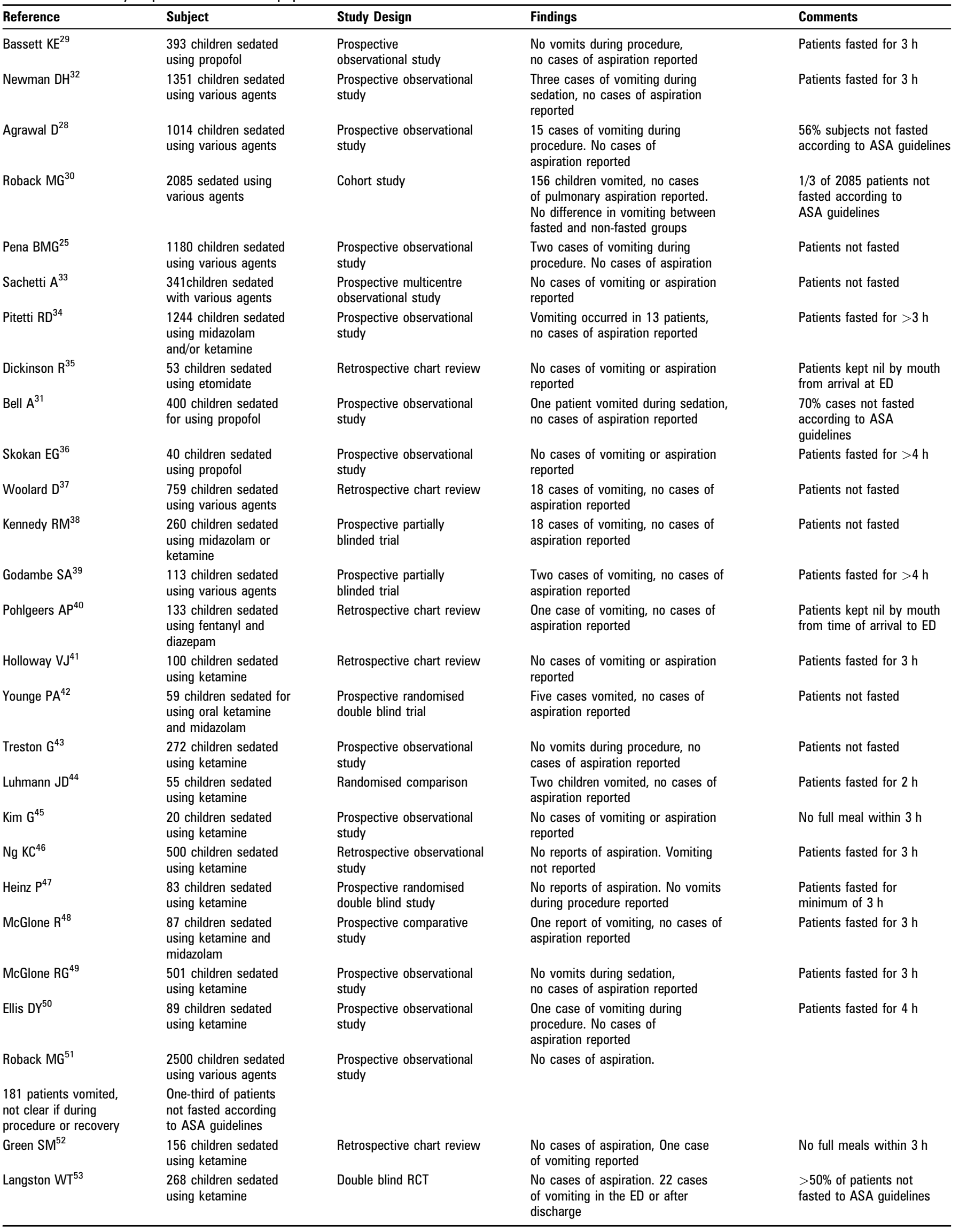


Table 4 Continued

\begin{tabular}{|c|c|c|c|c|}
\hline Reference & Subject & Study Design & Findings & Comments \\
\hline Pruitt $\mathrm{JW}^{54}$ & $\begin{array}{l}37 \text { children sedated } \\
\text { using ketamine } \\
\text { and midazolam }\end{array}$ & $\begin{array}{l}\text { Prospective observational } \\
\text { series }\end{array}$ & $\begin{array}{l}\text { No cases of aspiration reported, } \\
\text { one case of vomiting during } \\
\text { recovery phase }\end{array}$ & $\begin{array}{l}\text { No full meals within } 3 \mathrm{~h} \\
\text { of procedure }\end{array}$ \\
\hline Green $\mathrm{SM}^{55}$ & $\begin{array}{l}108 \text { children sedated } \\
\text { using ketamine }\end{array}$ & $\begin{array}{l}\text { Prospective uncontrolled } \\
\text { trial }\end{array}$ & $\begin{array}{l}\text { No cases of aspiration. One case of } \\
\text { vomiting during sedation }\end{array}$ & $\begin{array}{l}\text { No full meal within } 3 \mathrm{~h} \\
\text { of procedure }\end{array}$ \\
\hline McCarty $\mathrm{EC}^{56}$ & $\begin{array}{l}114 \text { children sedated } \\
\text { using ketamine }\end{array}$ & Prospective case series & $\begin{array}{l}\text { No cases of aspiration reported. } \\
\text { No cases of vomiting during } \\
\text { procedure }\end{array}$ & $\begin{array}{l}\text { No full meal within } 3 \mathrm{~h} \\
\text { of procedure }\end{array}$ \\
\hline Dachs $\mathrm{RJ}^{57}$ & $\begin{array}{l}30 \text { children sedated } \\
\text { using ketamine }\end{array}$ & $\begin{array}{l}\text { Prospective observational } \\
\text { study }\end{array}$ & $\begin{array}{l}\text { No cases of aspiration or vomiting } \\
\text { during procedure. Two cases of } \\
\text { post procedural vomiting }\end{array}$ & $\begin{array}{l}\text { Patients fasted for } 3 \mathrm{~h} \\
\text { for solids. }\end{array}$ \\
\hline Green $\mathrm{SM}^{58}$ & $\begin{array}{l}1022 \text { children sedated } \\
\text { using ketamine }\end{array}$ & $\begin{array}{l}\text { Prospective consecutive } \\
\text { case series }\end{array}$ & $\begin{array}{l}\text { No cases of aspiration reported, } \\
6.7 \% \text { of cases vomited }\end{array}$ & No full meal for $3 \mathrm{~h}$ \\
\hline Sherwin $\mathrm{TS}^{59}$ & $\begin{array}{l}104 \text { children sedated } \\
\text { using ketamine } \\
\text { and midazolam }\end{array}$ & $\mathrm{RCT}$ & $\begin{array}{l}\text { No cases of aspiration reported. } \\
\text { No cases of vomiting during } \\
\text { procedure }\end{array}$ & No full meal within $3 \mathrm{~h}$ \\
\hline Wathen $\mathrm{JE}^{60}$ & $\begin{array}{l}266 \text { children sedated } \\
\text { using ketamine } \\
\text { and midazolam }\end{array}$ & RCT & $\begin{array}{l}\text { No cases of aspiration reported. } \\
\text { No cases of vomiting during } \\
\text { procedure }\end{array}$ & $\begin{array}{l}\text { Length of fast varied } \\
\text { between } 3.6 \text { and } 8.1 \mathrm{~h}\end{array}$ \\
\hline Priestley $S J^{61}$ & $\begin{array}{l}28 \text { children sedated } \\
\text { using ketamine } \\
\text { and midazolam }\end{array}$ & $\begin{array}{l}\text { Prospective observational } \\
\text { study }\end{array}$ & $\begin{array}{l}\text { No cases of aspiration reported. } \\
\text { No cases of vomiting during } \\
\text { procedure }\end{array}$ & $\begin{array}{l}\text { Patients fasted for } 4 \mathrm{~h} \\
\text { for solids }\end{array}$ \\
\hline Luhmann JD ${ }^{62}$ & $\begin{array}{l}42 \text { children sedated } \\
\text { using various agents }\end{array}$ & $\begin{array}{l}\text { Consecutive prospective } \\
\text { case series }\end{array}$ & $\begin{array}{l}\text { No cases of aspiration reported. } \\
\text { One patient vomited. }\end{array}$ & $\begin{array}{l}\text { Fasting times between } \\
1.6 \text { and } 8.8 \mathrm{~h}\end{array}$ \\
\hline Losek JD ${ }^{63}$ & $\begin{array}{l}116 \text { children sedated } \\
\text { using ketamine } \\
\text { and midazolam }\end{array}$ & Retrospective chart review & $\begin{array}{l}\text { No cases of aspiration or } \\
\text { vomiting reported. }\end{array}$ & Patients not fasted \\
\hline Waterman $\mathrm{GD}^{64}$ & $\begin{array}{l}858 \text { children sedated } \\
\text { using ketamine }\end{array}$ & Retrospective chart review & $\begin{array}{l}\text { No cases of aspiration reported. } \\
10 \text { cases of vomiting }\end{array}$ & Patients fasted for $4 \mathrm{~h}$ \\
\hline Sharieff $\mathrm{GQ}^{65}$ & $\begin{array}{l}20 \text { children sedated } \\
\text { with ketamine } \\
\text { and propofol }\end{array}$ & $\begin{array}{l}\text { Prospective observational } \\
\text { study }\end{array}$ & $\begin{array}{l}\text { No cases of aspiration or } \\
\text { vomiting reported during } \\
\text { procedure }\end{array}$ & $\begin{array}{l}\text { Patients fasted for } 6 \mathrm{~h} \\
\text { for solids and } 4 \mathrm{~h} \text { for } \\
\text { liquids }\end{array}$ \\
\hline McKee $\mathrm{MR}^{66}$ & $\begin{array}{l}471 \text { children sedated } \\
\text { with ketamine }\end{array}$ & Retrospective chart review & $\begin{array}{l}\text { No cases of aspiration reported. } \\
17 \text { patients vomited }\end{array}$ & $\begin{array}{l}\text { Patients fasted for } 4 \mathrm{~h} \\
\text { for solids and } 2 \mathrm{~h} \text { for } \\
\text { liquids }\end{array}$ \\
\hline Langston $\mathrm{WT}^{53}$ & $\begin{array}{l}255 \text { children sedated } \\
\text { with ketamine }\end{array}$ & Double blind RCT & $\begin{array}{l}\text { No cases of aspiration reported. } \\
25 \text { patients vomited. }\end{array}$ & $\begin{array}{l}>50 \% \text { of patients not } \\
\text { fasted according to } \\
\text { ASA guidelines }\end{array}$ \\
\hline Acworth $\mathrm{JP}^{67}$ & $\begin{array}{l}53 \text { children sedated } \\
\text { with ketamine } \\
\text { and/or midazolam }\end{array}$ & Randomised trial & $\begin{array}{l}\text { No cases of aspiration reported. } \\
\text { One case of vomiting during } \\
\text { procedure }\end{array}$ & Patients not fasted \\
\hline Connors $\mathrm{K}^{68}$ & $\begin{array}{l}58 \text { children sedated } \\
\text { with midazolam }\end{array}$ & $\begin{array}{l}\text { Double blind, randomised } \\
\text { trial }\end{array}$ & $\begin{array}{l}\text { No cases of aspiration or } \\
\text { vomiting reported }\end{array}$ & Patients not fasted \\
\hline Shane $S A^{69}$ & $\begin{array}{l}34 \text { children sedated } \\
\text { with midazolam } \\
\text { or placebo }\end{array}$ & $\begin{array}{l}\text { Double blind randomised } \\
\text { trial }\end{array}$ & $\begin{array}{l}\text { No cases of aspiration or } \\
\text { vomiting reported }\end{array}$ & Patients fasted for $2 \mathrm{~h}$ \\
\hline
\end{tabular}

ASA, American Society of Anesthesiologists; ED, emergency department; RCT, randomised controlled trial.

\section{Results}

Three studies were found that specifically investigated the relationship between pre-procedural fasting and adverse effects. All three studies show no association between the two. Agrawal et $a l^{28}$ report a consecutive series of 1014 children undergoing procedural sedation, of whom $56 \%$ were not fasted in accordance with ASA guidelines. There were no reported cases of pulmonary aspiration, and 15 reported cases of vomiting. There were no differences in airway complications, vomiting or any other adverse events between fasted and non-fasted groups. Roback et $a l^{30}$ in a study of 2085 children undergoing emergency procedural sedation, found no association between pre-procedural fasting and incidence of adverse events. Although 156 $(7.5 \%)$ patients vomited there were no cases of pulmonary aspiration, and when the fasting time was divided into 2-h groups $(0-2,2-4,4-6,6-8$ and $>8 \mathrm{~h})$ no association was found. The higher rates of vomiting in this study compared to others may be explained by a higher percentage of cases sedated using ketamine. An observational study by Bell et al ${ }^{31}$ reports 400 cases of paediatric sedation using propofol for emergency procedures. Seventy per cent of cases had eaten between 2 and $6 \mathrm{~h}$ prior to the procedure. No adverse outcomes were reported. In this study two patients vomited, the first during sedation and the other after recovering to the extent of being able to talk. Neither case showed evidence of aspiration.

A number of other paediatric sedation papers are listed in table 4, describing 17672 cases of paediatric procedural sedation. There are no reports of pulmonary aspiration among them.

\section{Comment}

There are several important considerations when applying the evidence from paediatric emergency sedation to adults. Ketamine is generally used more commonly in children, although its use has been widely reported in all ages. Ketamine is known to produce a dissociative state, rather than true sedation or anaesthesia, ${ }^{55}$ and is therefore believed to be less likely to suppress protective airway reflexes. It is also thought to be more emetic than other drugs. ${ }^{70}$ The paediatric population as a whole 
are also believed to have a higher incidence of vomiting than adults. Nevertheless, there are no reports of pulmonary aspiration in children undergoing emergency procedural sedation, the majority of whom were not fasted in line with ASA guidelines.

\section{CONCLUSION}

The risk of aspiration during emergency procedural sedation is very low, and no evidence exists to support pre-procedural fasting. In several large case series of adult and paediatric emergency procedural sedation, there have been no published reports of pulmonary aspiration. Evidence to support ASA guidelines for fasting prior to general anaesthesia, which have been extrapolated for use in emergency sedation, has minimal scientific support. Indeed, several randomised trials have failed to show any link between non-fasted patients and pulmonary aspiration. Therefore, there is no reason to recommend fasting patients prior to procedural sedation in the ED.

However, selected patients believed to be significantly more prone to aspiration may benefit from a risk:benefit assessment prior to sedation. This assessment should consider the relative risks and benefits of the proposed procedure and sedation technique, including factors that may increase the risk of aspiration such as old age and conditions predisposing to gastro-oesophageal reflux.

Competing interests None.

Provenance and peer review Not commissioned; externally peer reviewed.

\section{REFERENCES}

1. Cheung KW, Watson ML, Field S. Aspiration pneumonitis requiring intubation after procedural sedation and analgesia: a case report. Ann Emerg Med 2007:49:462-4

2. Marik PE. Aspiration pneumonitis and aspiration pneumonia. N Eng/ J Med 2001;344:665-71.

3. Warner MA, Warner ME, Weber JG. Clinical significance of pulmonary aspiration in the perioperative period. Anaesthesiology 1993;78:56-62.

4. Olsson GL, Hallen B, Hambraeus-Jonzon K. Aspiration during anaesthesia a computer-aided study in 185,358 anaesthetics. Acta Anaesthesiol Scand 1986;30:84-92.

5. Mendelson CL. The aspiration of stomach contents into the lungs during obstetric anaesthesia. Am J Obstet Gynecol 1946:52:191-204.

6. Roberts RB, Shirley MA. Reducing the risk of acid aspiration during caesarean section. Anaesth Analg 1974;53:859-68.

7. American Society of Anaesthesiologists. Practice guidelines for preoperative fasting and the use of pharmacological agents to reduce the risk of pulmonary aspiration: application to healthy patients undergoing elective procedures. Anaesthesiology 1999:90:896-905.

8. Brady M, Kinn S, Stuart P. Preoperative fasting for adults to prevent perioperative complications (Review). Cochrane Database Syst Rev 2003;(4):CD004423.

9. Soreide $\mathbf{E}$, Holst Larson $\mathrm{H}$, Reite $\mathrm{K}$, et al. The effects of giving $25-450 \mathrm{ml}$ of water with diazepam premedication 1-2 hours before general anaesthesia. $\mathrm{Br} J$ Anaesth 1993:71:503-6.

10. Goodwin AP, Rowe WL, Ogg TW, et al. Oral fluids prior to day surgery. The effect of shortening the pre-operative fluid fast on postoperative morbidity. Anaesthesia 1991;46:1066-8

11. Hausel J, Nygren J, Lagerkranser $\mathrm{M}$, et al. A carbohydrate-rich drink reduces preoperative discomfort in elective surgery patients. Anaesth Analg 2001:93:1344-50.

12. Phillips S, Hutchinson S, Davidson T. Preoperative drinking does not affect gastric contents. Br J Anaesth 1993;70:6-9.

13. Gilbert SS, Easy WR, Fitch WW. The effect of per-operative oral fluids on morbidity following anaesthesia for minor surgery. Anaesthesia 1995;50:79-81.

14. Yagci G, Can MF, Ozturk E. Effects of preoperative carbohydrate loading on glucose metabolism and gastric contents in patients undergoing moderate surgery: a randomized, controlled trial. Nutrition 2008;24:212-16.

15. Engelhardt T, Webster NR. Pulmonary aspiration of gastric contents in anaesthesia. Br J Anaesth 1999;83:453-60.

16. Ljungqvist 0, Soreide E. Preoperative fasting. Br J Surg 2003;90:400-6.

17. Green SM, Krauss B. Pulmonary aspiration risk during ED procedural sedation: an examination of the role of fasting and sedation depth. Acad Emerg Med 2002;99:35-42.

18. Gleeson K, Eggli DF, Maxwell SL. Quantitative aspiration during sleep in normal subjects. Chest 1997;111:1266-72.
19. Blitt CD, Gutman HL, Cohen DD, et al. Silent regurgitation and aspiration during general anaesthesia. Anaesth Analg 1970;49:707-13.

20. Culver GA, Makel HP, Beecher HK. Frequency of aspiration of gastric contents by the lungs during anaesthesia and surgery. Ann Surg 1951;133:289-92.

21. Kallar SK, Everett LL. Potential risks and preventive measures for pulmonary aspiration-new concepts in preoperative fasting guidelines. Anesth Analg 1993:77:171-82

22. Cote CJ, Goudsouzian NG, Lui LM, et al. Assessment of risk factors related to acid aspiration syndrome in pediatric patients - gastric $\mathrm{pH}$ and residual volume. Anesthesiology 1982;56:70-2.

23. Lydon A, McGinley J, Cooke T, et al. Efffects of anxiety on the rate of gastric emptying of liquids. $\mathrm{Br} J$ Anaesth 1998;81:522-5.

24. Steedman DJ, Payne MR, McClure JH, et al. Gastric emptying following Colles' fracture. Arch Emerg Med 1991;8:165-8.

25. Pena BMG, Krauss B. Adverse events of procedural sedation and analgesia in a paediatric emergency department. Ann Emerg Med 1999;34:483-91.

26. Kovac AL. Prevention and treatment of postoperative nausea and vomiting. Drugs 2000;59:213-43

27. Green SM. Fasting is a consideration - not a necessity for emergency department procedural sedation and analgesia. Ann Emerg Med 2003:42:647-50.

28. Agrawal D, Manzi SF, Gupta R, et al. Preprocedural fasting state and adverse events in children undergoing procedural sedation and analgesia in a paediatric emergency department. Ann Emerg Med 2003:42:636-46.

29. Bassett KE, Anderson JL, Pribble CG, et al. Propofol for procedural sedation in children in the emergency department. Ann Emerg Med 2003:42:773-81.

30. Roback MG, Bajaj L, Wathen JE, et al. Preprocedural fasting and adverse events in procedural sedation and analgesia in a paediatric emergency department: are they related? Ann Emerg Med 2004:44:454-9.

31. Bell A, Treston G, McNabb C. Profiling adverse respiratory events and vomiting when using propofol for emergency department procedural sedation. Emerg Med Australas 2007:19:405-10.

32. Newman DH, Azer MM, Pitetti RD. When is a patient safe for discharge after procedural sedation? The timing of adverse effect events in 1,367 pediatric procedural sedations. Ann Emerg Med 2003:42:627-35.

33. Sachetti A, Stander E, Ferguson N. Pediatric procedural sedation in the community emergency department: Results from the proSCED registry. Pediatr Emerg Care 2007:23:218-22

34. Pitetti RD, Singh S, Pierce MC. Safe and efficacious use of procedural sedation and analgesia by non-anesthesiologists in a pediatric emergency department. Arch Pediatr Adolesc Med 2003;157:1090-6.

35. Dickinson $\mathbf{R}$, Singer AJ, Carrion W. Etomidate for pediatric sedation prior to fracture reduction. Acad Emerg Med 2001:8:74-7.

36. Skokan EG, Pribble C, Bassett KE. Use of propofol sedation in a pediatric emergency department: a prospective study. Clin Pediatr 2001;40:663-71.

37. Woolard DJ, Terndrop T. Sedative-analgesic agent administration in children: analysis of use and complications in the emergency department. J Emerg Med 1994:12:453-61.

38. Kennedy KM, Porter FL, Miller JP. Comparison of fentanyl/midazolam with ketamine/ midazolam for pediatric orthopedic emergencies. Pediatrics 1998;102:956-63.

39. Godambe SA, Elliot V, Matheny D. Comparison of propofol/fentanyl versus ketamine/ midazolam for brief orthopaedic procedural sedation in a pediatric emergency department. Pediatrics 2003;112:116-23.

40. Pohlgeers AP, Friedland LR, Keegan-Jones $L$. Combination fentanyl and diazepam for pediatric conscious sedation. Acad Emerg Med 1995;2:879-83.

41. Holloway VJ, Husain HM, Gautam V. Accident and emergency department led implementation of ketamine sedation in paediatric practice and parental response. $J$ Accid Emerg Med 2000;17:25-8.

42. Younge PA, Kendall JM. Sedation for children requiring wound repair: a randomised controlled double blind comparison of oral midazolam and oral ketamine. Emerg Med $J$ 2001;18:30-3

43. Treston G. Prolonged pre-procedure fasting time is unnecessary when using titrated intravenous ketamine for paediatric procedural sedation. Emerg Med Australas 2004; 16:145-50

44. Luhmann JD, Schootman M, Luhumann SJ, et al. A randomized comparison of nitrous oxide plus haematoma block versus ketamine plus midazolam for emergency department forearm fracture reduction in children. Pediatrics 2006:118:1078-86

45. Kim G, Green SM, Denmark TK, et al. Ventilatory response during dissociative sedation in children-a pilot study. Acad Emerg Med 2003;10:140-5.

46. $\mathbf{N g ~ K C , ~ A n g ~ S Y . ~ S e d a t i o n ~ w i t h ~ k e t a m i n e ~ f o r ~ p a e d i a t r i c ~ p r o c e d u r e s ~ i n ~ t h e ~ e m e r g e n c y ~}$ department-a review for 500 cases. Singapore Med J 2002;43:300-4.

47. Heinz $\mathbf{P}$, Geelhoed GC. Wee $\mathrm{C}$, et al. Is atropine needed with ketamine sedation? A prospective, randomised, double blind study Emerg Med J 2006;23:206-9.

48. McGlone R, Fleet T, Durham S, et al. A comparison of intramuscular ketamine with high dose intramuscular midazolam with and without intranasal flumazenil in children before suturing. Emerg Med J 2001;18:34-8.

49. McGlone RG, Howes MC, Joshi M. The Lancaster experience of 2.0 to $2.5 \mathrm{mg} / \mathrm{kg}$ intramuscular ketamine for paediatric sedation: 501 cases and analysis. Emerg Med $J$ 2004;21:290-5.

50. Ellis DY, Husain HM, Saetta JP, et al. Procedural sedation in paediatric emergency procedures: a prospective audit on ketamine use in the emergency department. Emerg Med J 2004;21:286-9. 
51. Roback MG, Wathen JE, Bajaj L, et al. Adverse events associated with procedural sedation and analgesia in a pediatric emergency department: a comparison of common parenteral drugs. Acad Emerg Med 2005;12:508-13.

52. Green SM, Rothback SG, Harris T, et al. Intravenous ketamine for pediatric sedation in the emergency department: safety profile with 156 cases. Acad Emerg Med 1998;5:971-6.

53. Langston WT, Wathen JE, Roback MG, et al. Effect of ondansetron on the incidence of vomiting associated with ketamine sedation in children: a double-blind, randomized, placebo-controlled trial. Ann Emerg Med 2008:52:30-4.

54. Pruitt JW, Goldwasser MS, Sabol SR, et al. Intramuscular ketamine, midazolam, and glycopyrolate for pediatric sedation in the emergency department. J Oral Maxillofac Surg 1995:53:317.

55. Green SM, Nakamura R, Johnson NE. Ketamine sedation for pediatric procedures: part 1, a prospective series. Ann Emerg Med 1990;19:1024-32.

56. McCarty EC, Mencio GA, Walker LA, et al. Ketamine sedation for the reduction of children's fractures in the emergency department. J Bone Joint Surg 2000;82-A: 912-18.

57. Dachs RJ, Innes GM. Intravenous ketamine sedation of pediatric patients in the emergency department. Ann Emerg Med 1997;29:146-50.

58. Green SM, Rothrock SG, Lynch EL, et al. Intramuscular ketamine for pediatric sedation in the emergency department: safety profile in 1,022 cases. Ann Emerg Med 1998;31:688-97.

59. Sherwin TS, Green SM, Khan A, et al. Does adjunctive midazolam reduce recovery agitation after ketamine sedation for pediatric procedures? A randomized, doubleblind, placebo-controlled trial. Ann Emerg Med 2000;35:229-38.

60. Wathen JE, Roback MG, Mackenzie T, et al. Does midazolam alter the clinical effects of intravenous ketamine sedation in children? A double-blind, randomized, controlled, emergency department trial. Ann Emerg Med 2000;36:579-88.

61. Priestley SJ, Taylor J, McAdam CM, et al. Ketamine sedation for children in the emergency department. Emerg Med (Fremantle) 2001;13:82-90.

62. Luhmann JD, Kennedy RM, McAllister JD, et al. Sedation for peritonsillar abscess drainage in the pediatric emergency department. Pediatr Emerg Care 2002;189:1-3.

63. Losek JD, Reid S. Effects of initial pain treatment on sedation recovery time in pediatric emergency care. Pediatr Emerg Care 2006;22:100-3.

64. Waterman GD Jr., Leder MS, Cohen DM. Adverse events in pediatric ketamine sedations with or without morphine pretreatment. Pediatr Emerg Care 2006;22:408-11.

65. Sharieff GQ, Trocinski DR, Kanegaye JT, et al. Ketamine-propofol combination sedation for fracture reduction in the pediatric emergency department. Pediatr Emerg Care 2007;23:881-4

66. McKee MR, Sharieff GQ, Kanegaye JT, et al. Oral analgesia before pediatric ketamine sedation is not associated with an increased risk of emesis and other adverse events. J Emerg Med 2008;35:23-8.

67. Acworth JP, Purdie D, Clark RC. Intravenous ketamine plus midazolam is superior to intranasal midazolam for emergency paediatric procedural sedation. Emerg Med $\mathrm{J}$ 2001;18:39-45

68. Connors $\mathbf{K}$, Terndrup T, Harris $\mathrm{E}$, et al. Oral versus nasal midazolam for sedation of anxious children requiring laceration repair. Ann Emerg Med 1994;23:611. [Abstract].

69. Shane SA, Fuchs SM, Khine H. Efficacy of rectal midazolam for the sedation of preschool children undergoing laceration repair. Ann Emerg Med 1994;24:1065-73.

70. Sacchetti A, Senula G, Strickland J. Procedural sedation in the community emergency department: Initial results of the proSCED registry. Acad Emerg Med 2007:14:41-6

71. Frazee BW, Park RJ, Lowery D, et al. Propofol for deep procedural sedation in the emergency department. Am J Emerg Med 2005;23:190-5.

72. Campbell SG, Magee K, Kovacs G, et al. Procedural sedation and analgesia in a Canadian adult tertiary care emergency department: a case series. Can J Emerg Med 2006;8:85-93.
73. Miner JR, Martel M, Meyer M. Procedural sedation of critically ill patients in the emergency department. Acad Emerg Med 2005;123:124-8.

74. Swanson ER, Seaberg D, Mathias S. The use of propofol for sedation in the emergency department. Acad Emerg Med 1996;3:234-8.

75. Chudnofsky CR, Weber JE, Stoyanoff PJ, et al. A combination of midazolam and ketamine for procedural sedation and analgesia in adult emergency department patients. Ann Emerg Med 2000;36:579-88.

76. Lerman B, Yoshida D, Levitt MA. A prospective evaluation of safety and efficacy of methohexitol. Am J Emerg Med 1996:14:351-4.

77. Miner JR, Biros M, Krieg S, et al. Randomised clinical trial of propofol versus methohexitol for procedural sedation during fracture and dislocation reduction in the emergency department. Acad Emerg Med 2003;10:931-7.

78. Vinson DR, Bradbury DR. Etomidate for procedural sedation in emergency medicine. Ann Emerg Med 2002;39:592-8.

79. Ruth WJ, Burton JH, Bock AJ. Intravenous etomidate for procedural sedation in the emergency department patients. Acad Emerg Med 2001;8:13-18.

80. Burton JH, Miner JR, Shipley ER, et al. Propofol for emergency department procedural sedation and analgesia: a tale of three centers. Acad Emerg Med 2006;13:24-30.

81. Coll-Vinent B, Sala X, Fernandez M. Sedation for cardioversion in the emergency department: analysis of effectiveness in four protocols. Ann Emerg Med 2003; 42:767-72

82. Miner JR, Biros M, Heegaard W, et al. Bispectral electroencephalographic analysis of patients undergoing procedural sedation in the emergency department. Acad Emerg Med 2003;10:638-43.

83. Sokolowski J, Niewinska K, Niewinski P, et al. Safety of etomidate administration for procedural sedation in elderly emergency department patients. Pharmacol Rep 2007:59:1734-140.

84. Willman EV, Andolfatto G. A prospective evaluation of "ketofol" (ketamine/propofol combination) for procedural sedation and analgesia in the emergency department. Ann Emerg Med 2007:49:0196-644.

85. Chan KLL. Etomidate and midazolam for procedural sedation in the emergency department of Queen Elizabeth Hospital: a randomised controlled trial. Am J Emerg Med 2008:15:75-87.

86. Engel J, Coyner M, Charles J. Propofol for procedural sedation in a rural emergency department[abstract]. Ann Emerg Med 2007;50:S122-3.

87. Dunn T, Mossop D, Newton A, et al. Propofol for procedural sedation in the emergency department. Emerg Med J 2007;24:459-61.

88. Miner JR, Danahy M, Moch A, et al. Randomised clinical trial of etomidate versus propofol for procedural sedation in the emergency department. Ann Emerg Med 2007:49:15-22.

89. Newton A, Fitton L. Intravenous ketamine for adult procedural sedation in the emergency department: a prospective cohort study. Emerg Med $J$ 2008;25:498-501.

90. Vardy JM, Dignon N, Mukherjee N, et al. Audit of safety and effectiveness of ketamine for procedural sedation in the emergency department. Emerg Med 2008;25:579-82

91. Sim TB, Seet CM. To study the effectiveness and safety of ketamine and midazolam procedural sedation in the incision and drainage of abscesses in the adult emergency department. Eur J Emerg Med 2008:15:169-72.

92. Messenger DW, Murray HE, Dungey PE, et al. Subdissociative-dose ketamine versus fentanyl for analgesia during propofol procedural sedation: a randomized clinical trial. Acad Emerg Med 2008:15:877-86.

93. Wright SW, Chudnofsky CR, Dronen SC, et al. Comparison of midazolam and diazepam for conscious sedation in the emergency department. Ann Emerg Med 1993:22:201-5.

94. Green SM, Sherwin TS. Incidence and severity of recovery agitation after ketamine sedation in young adults. Am J Emerg Med 2005:23:142-4. 